\title{
Pure Spirits: Imperial Japanese Justice and Right-Wing Terrorists, 1878-1936
}

\author{
Danny ORBACH*
}

\begin{abstract}
Why was the legal system in 1930s Japan so friendly to right-wing offenders, even when they tried to assassinate leading statesmen and generals? The answer is intertwined with a cultural narrative defined here as "subjectivism", that assigned vital importance to a criminal's subjective state of mind when evaluating his or her transgressions. Though influenced by Western thought, this narrative was indigenous to Japan. It originated in the late Edo period, shortly prior to the establishment of the Meiji State in 1868, under specific historical circumstances and was later reinforced by the policy of the early Meiji State. Consequently, it pervaded education, politics and popular discourse alike, in the civilian sphere and even more so in the army.

Until the early 1920s, this trend had a relatively modest influence on the Japanese justice system. It then began to gain traction in military courts dealing with political crimes of army personnel. From 1932 it influenced civilian courts as well, though civilian judges were relatively more reluctant to accept it than their military peers. After a peak in the mid-1930s, it again receded into the background, following the abortive coup d'état of February 26, 1936.
\end{abstract}

Keywords: Modern Japan, Japanese law, legal history, subjectivism, political terrorism

\section{Nepokvarjeni duhovi: pravosodje $\mathrm{v}$ Japonskem cesarstvu in desničarski ter- oristi med letoma 1878 in 1936}

\section{Izvleček}

Zakaj je bil japonski pravni sistem $\mathrm{v}$ tridesetih letih 20. stoletja tako prizanesljiv do desničarskih prestopnikov, tudi tistih, ki so poskušali izvesti atentate na vodilne državnike in generale? Odgovor lahko najdemo v ideološkem diskurzu, ki ga tu definiramo kot "subjektivizem" in ki je pri obravnavanju kršitev za najpomemnbejši faktor prepoznal subjektivno stanje duha kriminalcev. Čeprav je bil prežet z zahodno miselnostjo, gre za domoroden japonski diskurz. Izvira iz posebnih zgodovinskih okoliščin poznega obdobja Edo, tik pred ustanovitvijo mejdžijevske države leta 1868, ki ga je s svojo politiko pozneje utrdila. Zaradi tega je imel ta diskurz velik vpliv v civilni sferi in še bolj v vojski, pri čemer ga lahko prepoznamo v izobraževanju, politiki in popularni kulturi.

Danny ORBACH, $\mathrm{PhD}$, Hebrew University of Jerusalem. dannyorach[at]gmail.com

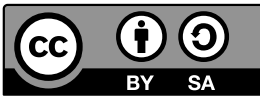


Do začetka dvajsetih let 20. stoletja $\mathrm{v}$ japonskem pravosodnem sistemu ta trend ni imel večje vloge, nato pa je postajal vse bolj izrazit na vojaških sodiščih, ki so obravnavala politično motivirana kazniva dejanja vojaškega osebja. Od leta 1932 se je v manjši meri razširil tudi na civilna sodišča, četudi so bili civilni sodniki bolj zadržani. Vrhunec je trend dosegel sredi tridesetih let, nato pa se je po neuspelem državnem udaru 26. februarja 1936 ponovno umaknil v ozadje.

Ključne besede: moderna Japonska, japonsko pravo, pravna zgodovina, subjektivizem, politični terorizem

In October 1931, the Japanese Imperial Army uncovered one of the most dangerous plots in the history of pre-war Japan. Teams of military policemen, accompanied by newspaper reporters and camera crews, surrounded a pub and arrested a group of officers within. This cabal, the inner circle of an underground organisation called the Sakura-kai (Cherry Blossom Society), had plotted to wipe out Japan's civilian and military leadership with machine guns, naval bombers and poisonous gas. After this bloodbath, the group had planned to install as prime minister General Araki Sadao, the leader of the radical-reformist "Imperial Way Faction", and to launch the "Showa Restoration": a reform plan encompassing social justice at home and relentless imperial expansion abroad.

After the arrest of the ringleaders, the chief of the Military Police declared that he would treat them "according to the spirit of bushido", the Japanese way of the warrior. Accordingly, the plotters received a "punishment" of ten days detention in a luxurious inn, with alcohol and geisha. Some of them were quietly released from the army, while others resumed their military careers as if nothing had happened (Orbach 2017, 215, 218-9). ${ }^{1}$

In the interwar period, Japan was not unique in treating right-wing terrorists with such leniency. In Weimar Germany, terrorists from the right received far milder sentences, on average, than those associated with communist and socialist parties. In the 1920s, the German judicial system was a holdout of the previous Imperial Regime, and many judges looked at the Republic's government with open hostility. The judiciary, especially in the early and late years of the Republic, was a right-leaning oppositional force and naturally sympathised with right-wing defendants. ${ }^{2}$ In other countries, such as interwar Poland, the courts showed leniency

1 This article is based in part on my research for the aforementioned book. I would like to thank the Azrieli Foundation and the Harry S. Truman Institute in the Hebrew University of Jerusalem, for their generous financial assistance for the duration of this project.

2 One of the newest studies on this subject is: Anthony McElligott's Rethinking the Weimar Republic $(2014$, 99-101). For comparative statistical data on the punishment of left- and right-wing political murderers in the early years of the Weimar Republic, see Emil J. Gumpel's classic work Vier Jahre politischer Mord (1922, 81). 
to rioters who carried out violence against minorities. ${ }^{3}$ Such an approach may seem unfair from our point of view, but it is relatively straightforward to explain.

In Japan, however, this leniency is not as easy to comprehend. The judiciary did not sympathise with any oppositional force, as in Weimar Germany. In fact, it was strictly loyal to the Imperial Regime. And yet, the Sakura-kai received a mere slap on the wrist for planning to wipe out the cabinet. Then, in May 1932, the murderers of Prime Minister Inukai Tsuyoshi received jail sentences of three to 15 years instead of the death penalty. Indeed, this is one of the most intriguing questions in pre-war Japanese history: why did leaders, politicians, officers and jurists treated with such leniency the very people who tried to kill them, or at least overthrow the regime they represented?

This problem was recently tackled by John D. Person in his study on the policing of far-right groups during the 1930s. In his analysis, Person $(2017,289-319)$ explains the relative failure of Japanese law enforcement agencies to neutralise right-wing terrorist groups, even though senior police officers understood how dangerous they were. Person's analysis clearly shows that officers in organs charged with fighting such groups, such as the Justice Ministry, the Special Higher Police and the Military Police, did so with great reluctance and circumspection, and not without emotional difficulty. In a speech to younger officials, given in October 1938, veteran procurator Sano Shigeki confessed that his relentless struggle against rightwing terrorists had made him and his colleagues "battle weary, and at times we would like to pass on the baton [...] sooner rather than later" (Person 2017, 290). Even after right-wing terrorists assassinated national leaders in the early 1930s, the law enforcement agencies had to apply soft methods of control. When the police finally decided on a crackdown in May 1935, it had to mask the arrests of right-wing activists under the aegis of a general campaign against criminal violence (this approach was possible because many nationalist groups were also engaged in extortion and other non-political crimes) (Person 2017, 299, 313) 4

Person offers several explanations for the laxity of Japanese law enforcement in controlling right-wing violence. Some of them are organisational, such as the failure of the various agencies to coordinate with one another. Others are more ideological. The state, he argues, found it difficult to deal with right-wing nationalism because it was a radicalised version of official state ideology (Person, 293-4, 307, 318). Wagatsuma Sakae offered a very similar explanation, focusing on the difficulty of punishing transgressors who expressed loyalty to the Emperor, to

3 See for example: Cooper 2000, 68.

4 Richard H. Mitchell's (1922) thorough study of political justice in Japan focuses mainly on communist defendants, and hardly touches the question of their motives as a factor in sentencing. 
whom law enforcers felt more committed than to the letter of the law (Wagatsuma 1968-70, 453-63).

Yet why did the state put such a strong emphasis on the ideas of political terrorists rather than on the consequences of their criminal actions? The source of this emphasis, I will argue in this paper, went back decades, and was intertwined with an often-overlooked cultural narrative that was prevalent in pre-war Japan. This narrative, which I will call "subjectivism", assigned vital importance to a criminal's subjective state of mind when evaluating his or her transgressions. Though influenced by Western thought, this narrative was indigenous to Japan. It originated in the late Edo period, shortly prior to the establishment of the Meiji State in 1868, under specific historical circumstances and was later reinforced by the policy of the early Meiji State. Consequently, it pervaded education, politics and popular discourse alike, in the civilian sphere and even more so in the army.

Until the early 1920s, this trend had a relatively modest influence on the Japanese justice system. It then began to gain traction in military courts dealing with political crimes of army personnel. From 1932 it influenced civilian courts as well, though civilian judges were relatively more reluctant to accept it than their military peers. After a peak in the mid-1930s, it again receded into the background, following the abortive coup d'état of February 26, 1936. Why this was the case is our concern for the remainder of this paper.

\section{Ideological Genesis: Subjectivism and the Ideals of the Shishi}

The Imperial Meiji regime (1868-1945) was created by a group of revolutionary samurai who fought against the Tokugawa shogunate during the 1860s. Many of these people, widely known as shishi (warriors of high aspiration), began their careers as terrorists who attacked foreigners and shogunate officials under the slogan sonnōjöi (Revere the Emperor and Expel the Barbarians). As scions of lowand middle-ranking samurai families, they felt underprivileged by the regime, by the worsening living conditions of their class and by a series of economic crises that hit the country in the nineteenth century. In 1853, when the shogunate was coerced by the Americans into opening Japan up to foreign trade, such samurai found xenophobic rage a convenient outlet for their multiple frustrations. They rallied against the shogun who failed to protect the country from the "foreign barbarians". At the same time, influenced by the ideology of "national studies" (kokugaku), they revered the distant Emperor in Kyōto, hitherto only a powerless nominal ruler (Huber 1982). 
Throughout the 1860s, some leaders of the shishi movement gradually shed their original xenophobic ideas, cooperated with representatives of Western powers and adapted themselves to pragmatic power politics. In January 1868, backed by the military power of the Chōshū and Satsuma domains, they led a revolutionary alliance against the shogunate. Seizing power after a short civil war, the new leaders launched radical Western-style reforms in a volte-face from their original xenophobic platform. ${ }^{5}$

One idea popular among the shishi, including people who became national leaders after 1868, was an emphasis on the subjective state of mind of an individual above and beyond the consequences of his or her actions. According to this ideology of subjectivism, the state of mind of an ideal shishi had to include several components:

1. Spontaneity - The shishi was expected to act violently when feeling righteous indignation, because spontaneous outbursts of emotion showed the purity of one's feelings and intentions. Lack of planning and calculation was an important part of this ideal (Harutoonian 1970, 193; Jansen 1994, 98-99, 136; Satow 1998, 71).

2. Sincerity - In shishi circles, terms such as madness $(k y \bar{o})$ and folly $(g u)$ were positive markers, denoting an individual's sincere readiness to sacrifice his life (Harutoonian 1970, 221-2) ${ }^{6}$. In 1860, when a contingent of shishi from the Tosa domain made their way to Edo, some of them wanted to disembowel themselves "to push the others to greater heroism", and were dissuaded "only with great difficulty" (Jansen 1994, 136). Such a move made no personal sense: it was only an extreme way to display a sincere readiness to die for the cause.

3. Pure Motives - A shishi may be mistaken, may do harm and even fight on the wrong side. Yet he had to have proper motives. A pure-hearted shishi was not only spontaneous and sincere, he also had to intend to fight for the realm and the Emperor-not for private gain, nor for any particular group in society. Of course, many shishi were brimming with private desires, and highly concerned with personal honour and interest groups (such as their feudal domains), but in order to be taken seriously they had to create an impression that they worked for the Emperor, the realm and the public good. It is crucial to note here that the public good was always associated with the Japanese monarchy. It was next to impossible to be a shishi without being an imperial loyalist (Orbach 2017, 13).

$5 \quad$ For a thorough study of the Meiji Restoration, see Beasley 1972.

6 See also Walthall 1998, 183; Sasaki 1984, 124-5. For the observations of a leading Japanese statesman regarding the difference between madness, or foolhardiness, as a virtue, and madness in the normal sense of the word, see: Ōkuma 1969, 269. 
Shishi subjectivism was a homegrown ideology, and at that time still uninfluenced by similar ideas common in the West (for example, among German romanticists). It sprang from indigenous ideological sources, including philosophical schools who influenced some of the shishi as youths (Morris 1988, 191-3, 215, 235-6; Harutoonian 1970, 221-4, 387). Psychological reasons were also paramount. The shishi lived in a confusing, constantly changing world, where one could have little clue what consequences one's action would bring. The arrival of the foreigners in Japan, the chaos in the shogunate, the general crisis in the country and inside many domains, had cast doubts on accepted values and vested sources of authority. To paraphrase Jean-Francois Lyotard, the upheavals on the 1850s and 1860s were akin to an earthquake that destroyed not only lives and buildings, but also the tools used to measure earthquakes (Lyotard 1988, 56). In the confusion, many shishi felt the only thing they could rely on was the purity of their own motives. It therefore made sense to fetishize one's state of mind and to minimise the importance of consequences (Orbach 2017, 13-14).

\section{Myth of the Shishi: Subjectivism and Commemoration in the Meiji Period}

After the Meiji Restoration of 1868, subjectivism did not disappear. Instead, it was gradually reinforced by two subsequent developments: The need to explain the reformist policy of the new leaders, and the commemoration policy designed to revere the heroes of the Meiji Restoration.

The leaders of the Restoration, many of them former shishi, had gained power from a xenophobic platform, vowing to "revere the Emperor and expel the barbarians." And yet, they embarked on an unprecedented, ambitious project of Western-style reforms. Many of their followers were obviously disgruntled. In such a situation, it was expedient to argue that the Meiji leaders' state of mind was subjectively pure. Whether they advocated expelling the barbarians or opening the country wide to Western influence, they were moved by imperial loyalty and sincere patriotism. The premium placed on spontaneity, responding instantly to the needs of the moment, was yet another good way to explain their volte-face. Itō Hirobumi, a rising star in the Meiji leadership and a former shishi from the Chōshū domain, explained his clique's change of policy in the following words: "When you look back on the things that happened then, they are impossible to understand. But emotionally, it had to be that way" (Craig 1961, 189).

The formal commemoration policy had also played an important role in the growth of subjectivism as a cultural narrative. When the Yasukuni Shrine was 
established in 1875 to honour those who had fallen in the Restoration Wars, the government decided to commemorate shishi who fell prey to the enforcement of shogunate law during the 1860s (Takata 2012, 43-52, 67-68). Many regional officials sought to maximise the number of local heroes, and petitioned to honour even shishi who were executed by the Meiji Government itself, such as those who illegally killed French sailors in the infamous Sakai Incident (1868). Such requests included conventional justifications for the applicants' transgressions (such as self-defence) but were almost always grounded also in their pure motives and sincerity (sekisei). Even if they were wrong, these shishi sincerely believed they were serving the Emperor (Takata 2012, 50-52).

The government often refused to honour such requests, but sometimes conceded in the long term. In 1913, it finally agreed to enshrine as shishi even samurai who had fought against the founders of the Meiji regime, as long as they sincerely believed they had followed the Emperor's will. However, those whose actions were "completely" against the imperial cause, those who knowingly disregarded the Emperor's will, would not be recognised. One's subjective state of mind thus became the most important determinant of commemoration (Jungoku Shishi 1913).

\section{Shishi, Subjectivism and Political Assassinations}

By commemorating the shishi, the government helped to create a subversive narrative. Already in the 1870s, assassins and rebels who worked against the new regime identified themselves implicitly or explicitly with shishi traditions, including the ideal of subjectivism. The gang of former samurai who tried to kill Iwakura Tomomi, the minister of the right, in 1874, saw themselves as spontaneous, sincere shishi who attacked government officials in order to save the Emperor and the country. ${ }^{7}$ The ringleaders of the Saga Rebellion (February to April 1874) denounced the Meiji Government as a "new shogunate", and used the shishi as explicit role models. ${ }^{8}$

Saigo Takamori, the most dangerous rebel leader in the 1870s, highly valued sincerity and purity of motives. Prior to his Satsuma Rebellion (1877), he reportedly said that "It is difficult to control a man who neither cares about life, status, wealth or honour. Without such unmanageable people, everyone has to suffer and it is impossible to do great things for the country" (Sagara 1978, 13). Saigō's disciples

$7 \quad$ Iwata to his parents, 28.3.1874, in Fukushima 1927, 121.

8 Testimonies of Takaki Hidetomi and Etō Shimpei in Matono Heisuke (Etō Nanpaku 1914, 411-2, 559-60), and the account of the conversation with Itagaki in Matono, Etō Nanpaku 1914, 2:40910 Etō's statement in Matono, Etō Nanpaku 1914, 559-60. 
and successors, who established nationalist societies such as the Genyōsha (Society of the Narrow Sea) and the Kokuryükai (Amur River Society), presented a propaganda narrative of direct continuity between the shishi of the 1860s, rebellions during the 1870s and political violence in the 1880s. ${ }^{9}$ Members of such societies frequently used the term minkan shishi (shishi of the people) or other synonyms, such as yüshi, dōshi or kokushi. (Kikuchi 1896, 503; Kuzu 1933-6, 1: 517; Chae $2001,440,45-7)^{10}$. They tried to imitate the behaviour of their role models in various ways, including by adopting subjectivist narratives. Members of patriotic societies and other violent political actors in the Meiji period and beyond boasted values such as spontaneity, sincerity and pure patriotic motives, even when they were busy profiteering from regular crime (Byas 1942, 226; Siniawer 2008, 108-9; Sekigawa 2014, 100-1, 106, 125; Kingsberg 2014 ).

The activity of such people sometimes resulted in murderous violence against government officials. On February 12, 1889, ultranationalist activist Nishino Buntarō stabbed the Education Minister Mori Arinori to death because he felt Mori had shown irreverence to the Sun Goddess during his visit to the Ise Shrine. While the government strongly condemned the assassination, large parts of the press extolled Nishino as a hero, and folk songs about his bravery became common and popular (Hall 1973, 3-5; Plutschow 2002, 144).

A few months later, Foreign Minister Ōkuma Shigenobu was gravely injured when a bomb was thrown into his carriage. The perpetrator, Kurushima Tsuneki, a member of the nationalistic society Genyōsha, wanted to protest Ōkuma's "softness" in the negotiations to revise the unequal treaties with the Western powers. The assailant committed suicide, after bowing three times towards the Imperial Palace (Norman 1944, 270).

In accordance with the ideals of subjectivism, even Ōkuma voiced admiration for his would-be murderer. "I don't think he was a madman or a loathsome person [...] comparing him with the weakling youngsters of today, who worry about bread, sob and cry abundantly for women [...] he is truly a wonderful person. I am touched by the bravery, even foolhardiness, of throwing a bomb at myself, the foreign minister, thereby upsetting public opinion [...] It will not do, if young people don't have a vigour that knows no boundaries, strong enough to swallow the entire

9 The narrative of such continuity is strongly expressed in the account of the Kokuryūkai on its own history. It often invokes the shishi, begins with the Restoration and the rebellions of the 1870s, and goes on to extoll the activities of the Genyōsha and the Kokuryūkai in later years. See: Kuzu (1933-6).

10 Kobayakawa Hideo, an activist who participated in the assassination of the Korean Queen in 1895, used the terms $d \overline{o s h i}$ (brethren), yūshi or minkan shishi to describe his friends. See: Kobayakawa $1900,41,52,75,88,91-2$. 
world." Ōkuma even transferred regular payments to his assailant's bereaved family (Ōkuma 1969, 1:269, 271; Lebra 1973, 89). By imitating the foolhardiness, sincerity and pure motives of a shishi, the assassin pushed the right emotional buttons, winning over even the heart of his victim.

\section{A Dormant Trend: Subjectivism in Political Assassination Trials until the Early 1920s}

The shishi myth and the related ideal of subjectivism had great impact on right-wing political terrorists, as well as some leverage as a cultural narrative. They had strong currency among the activists of nationalist societies and even among leaders who were targeted by right-wing terrorists, such as Ōkuma Shigenobu. Their practical influence on the judiciary, however, was relatively modest until the early 1920s.

This tendency owed, at least in part, to the legal theory of the time. Throughout the history of modern Japan, Japanese jurisprudence was significantly influenced by Western ideas. From the early Meiji period and until the enactment of the new penal code in 1907, and to some extent well into the 1920s, the foreign legal theory most popular in Japan emphasised deterrence and retribution, and thus focused more on a defendant's objective violation of the law rather than on his motives and state of mind. Therefore, the judiciary was relatively immune to the influence of shishi subjectivism (Kenzo 1963, 15-18).

The trials of political assassins from 1877 to 1916 reflected this prevailing theory. After the government defeated the Satsuma Rebellion in 1877, right-wing assassins made several attempts to kill major national leaders. In 1878, a vengeful former samurai assassinated the Home Minister Ōkubo Toshimichi. 1882 saw a failed attempt to kill Itagaki Taisuke, the leader of the oppositional Movement for Freedom and People's Rights. In 1889, as we have seen, Mori Arinori was killed, and Ōkuma Shigenobu was injured. In 1916, there was yet another failed attempt to kill Ōkuma Shigenobu, who by then was prime minister.

Only in the attempts to kill Ōkubo in 1878, Itagaki in 1882, and Ōkuma in 1916, were the assassins caught alive to face trial. Ökubo's assassin was sentenced to death and beheaded relatively quickly, as was usually the case with rebels in the 1870s. Though Itagaki's assailant tried to present himself as a spontaneous and sincere patriot with pure motives, this did not play a significant role in his sentencing. The procurator warned that if political assassinations "for the public good" were condoned, society would be flooded with political violence, and the public good would suffer. The judges agreed with the prosecution's anti-subjectivist 
stance, and sentenced the defendant to life imprisonment without considering his pure motives as mitigating circumstances (NSSS 1:528, 531-2). ${ }^{11}$ In the trial of Ökuma's assailant in 1916, the motives of the assassin were not really brought up as an argument in his favour, not even by the defence (NSSS 3:135-67).

Still, even in these trials, as in all political trials in the period, the sentences almost always began with a lengthy description of the defendant's motives. This did not really help the accused in the aforementioned cases. And yet, if they wanted, judges could show leniency to criminals with pure and patriotic motives. The prevailing legal doctrine in Japan allowed the judiciary to treat some offenders leniently according to their [the judges'] discretion. Since the 1880s, it was possible for a judge to use common sense (döri) when sentencing a defendant. In other words, judges had great leeway in evaluating the evidence and mitigating circumstances in any given case. ${ }^{12}$ In addition, article 165 in the Meiji Code of Criminal Procedure endowed judges with a sweeping power to acquit a defendant whenever they believed that the evidence for the case was inadequate (Keiji Soshohō 1890-1, 50).

As I have argued in my recent book, there is some reason to believe that this judicial flexibility helped the defendants in the Queen Min assassination incident of 1895. In that year, the Japanese envoy in Korea, Miura Gorō, and his associates, were accused of murdering the Queen of Korea in clear defiance of the Japanese government's policy. They were all acquitted based on article 165, despite overwhelming evidence against them. The sincerity and pure motives of the defendants were explicitly mentioned in the sentence of the Hiroshima Court of Preliminary Enquiries that tried the civilians. The secret correspondence of the military tribunal that judged the soldiers betrayed similar sentiments. It is possible that such sentiments played a role in the otherwise inexplicable decisions of both tribunals $^{13}$ (NSSS 2:231; Orbach 2017, 122-4).

In the High Treason Incident, the plot of an anarchist group to assassinate the Meiji Emperor in 1910, subjectivism played a discernible, though limited, role. During the trial, the defendants' state of mind and motives for the crime were repeatedly mentioned. After a short description of the suspects' immersion in anarcho-communism, the verdict explained their intention to assassinate the Emperor as a natural outgrowth of their ideology. "The defendants, as people deeply devoted to anarcho-communism,

11 Verdict against Aihara Naobumi, 28.6.1882, reproduced in NSSS 1:531-2.

12 John Haley $(1991,85)$ argues that "common sense" was often used to adapt the letter of the law to existing values.

13 The sympathy of the military tribunal towards the motives of the defendants was more implicit than in the civilian court, and the discussion here was intertwined with debate on obedience to illegal orders. See: Ichikawa 1953, 228-30, 248-9. 
wanted to destroy the authority of the state. In order to do that, they had to first remove or eliminate the head of state towards whom all subjects of the empire are obliged, to extinct the world-unique majesty of the kokutai, whose sacred blessing and virtue shines over the four seas. They plotted historically unprecedented, crooked treason against the inviolable body of the holy Emperor." ${ }^{14}$ People who worked against the Emperor could never be sincere, and were crooked by definition.

As every defendant shared the anarcho-communist ideas of his peers, it did not matter whether he actually did anything wrong. His motives, deemed evil by definition, already doomed him to capital punishment. Indeed, according to later evaluations, at least some of the defendants were sentenced to death based on extremely weak and tenuous evidence. As purity of motives was one and the same with imperial loyalty, the motives of anarchists were ipso-facto impure. Their condemnation followed this basic assumption. ${ }^{15}$

Notwithstanding these examples, shishi subjectivism still had a very limited role in civilian jurisprudence in the early 1920s. At the same time, however, it gained traction in the radical right, the Imperial Army and the military justice system.

\section{The Upsurge of Subjectivism: Sea Change in the Early 1920s}

In the 1910s and 1920s, the shishi cult enjoyed especially high currency in the Japanese Imperial Army. Since the end of the Russo-Japanese War in 1905, generations of Japanese military thinkers put an increasing emphasis on the "military spirit" of brave warriors who fight and persevere against materially superior enemies. Unlike military thinkers of prior generations, who modelled themselves on Western armies, the proponents of "spirit" looked back to an imagined Japanese past (Humphreys 1995, 12-13). As Oleg Benesch has written, the ideology of bushido, the way of the warrior, invented as an ethical system in the late Meiji period, was readily adopted by the army to fit the new model of military spirituality. ${ }^{16}$

In addition, the tactical doctrine of "operational discretion" (dokudan senkō), an import from German military thought, gave junior officers the right to make tactical decisions in the field, even against orders. That doctrine quickly expanded in the 1910s and 1920s, when the army became busy in small military operations on the Chinese mainland. The secret and sensitive nature of such operations demanded

14 Verdict against Kōtoku Denjirō and 25 others, 18.1.1911, reproduced in NSSS 2:560.

15 Verdict against Kōtoku and others, in NSSS 2:560, 566; Mackie and Yamaizumi 2013,1-4; Hirano 292-3). 
quick decisions from junior officers, and doctrine developed accordingly (Jōhō 1973, 229; Suzuki 1971-4, 1: 299).

Japanese military leaders often associated operational discretion with older shishi archetypes of spontaneity, sincerity and pure motives. General Ugaki Kazushige, the Army Minister from 1924 to 1927, wrote that operational discretion was "the basis for the soldier's spiritual life". In any case, a soldier must never hesitate. Whether he obeys or disobeys, that has to be spontaneously decided in an instant, according to the requirements of the moment (Tsunoda 1968-71, 1: 667). It is therefore unsurprising that by the early 1920s, glowing descriptions of the shishi were appearing in military textbooks. ${ }^{17}$

By the early 1920s, the currency of shishi ideals among officers was also influenced by civilian nationalist agitation. A new generation of nationalist rabble-rousers blamed the "privileged" classes_old feudal cliques, corrupt politicians, rapacious businessmen, cunning court nobles - for robbing and mistreating the Japanese people at home, while grovelling before foreigners abroad. In a stream of inflammatory pamphlets, right-wing groups called to imitate the shishi and kill members of the "privileged classes" without prior planning. In April 1920, an army officer named Asahi Heigo responded to such calls and killed the business magnate Yasuda Zenjirō. Asahi committed suicide, leaving behind a manifesto denouncing the privileged classes and calling for a new Restoration. The killing of Yasuda, said to be wicked profiteer, was a "divine punishment" (tenchü) and a spontaneous act of "folly" $(g u)$. Using these two terms, closely associated with the historical shishi, Asahi described himself and his friends as follows:

My fellow young idealists [shishi]! Your mission is to bring about a Taishō restoration [...] Do not speak, do not get excited, and do not be conspicuous. You must be quiet and simply stab, stick, cut and shoot. There is no need to meet or to organize. Just sacrifice your life. And work out your own way of doing this. In this way you will prepare the way for the revolution. The flames will start here and there, and our fellow idealists [dōshi-a common synonym of shishi] will band together instantly. So forget about self-interest, and do not think about your own name or fame. Just die, just sleep. Never seek wisdom, but take the road of ignorance and come to know the height of great folly $\left[\right.$ tai-gu.$^{18}$

17 See for example: Matsumoto 1937, 2: 7-9 (private collection of Prof. Carter Eckert, courtesy of Carter Eckert). See also Yamashita Fumio's essay in the same collection, 2: 13.

18 The translation is taken from Sources of Japanese Tradition, Ryusaku Tsunoda et. al, 1958, 768-9. The term "divine punishment" (tench $\bar{u}$ ) appears in the title of the document, which was not translated in Sources of Japanese Tradition. For the full Japanese original see: Shinkoku.exblog 2008. 
Asahi's call influenced civilian nationalists as well. After the railroad switchman Nakaoka Kon'ichi stabbed Prime Minister Hara Takashi to death on November 4,1921, he repeated in his trial ideas very similar to Asahi's. Nakaoka and his defence counsel tried to present him (Nakaoka) as a modern shishi. The assassin told the court that he was an ardent reader of shishi stories. His father used to praise the terrorists who killed Education Minister Mori Arinori and badly wounded Prime Minister Ōkuma Shigenobu in 1889. In 1920, Nakaoka decided he wanted to become a shishi himself and inscribe his name in history as a national hero through the assassination of Prime Minister Hara, the leader of the privileged classes (NSSS 3:313-9, 324-5).

Initially it seemed that Nakaoka had main the right emotional claim. The judge in the court for preliminary enquiries confirmed the indictment against him, yet remarked that "he holds the ideal of loyalty to the Imperial House. Such people are rare today." When the defendant elaborated on his motives, the judge was deeply touched and cried along with him (NSSS 3:326). In the main trial that followed, however, the procurator was not impressed and asked for the death penalty. Predictably, the defence attorneys asked for leniency based on the defendant's motives. There are so many bogus shishi and patriots in today's Japan, they said, that it would be a pity to execute a true patriot such as Nakaoka.

The judge finally sentenced Nakaoka to life with hard labour but refused to consider the defendant's motives as mitigating circumstances. In the verdict, the word shishi was mentioned only in reference to Nakaoka's self-perception, but the judge described him, and Asahi Heigo, his main source of inspiration, not as shishi but as criminals, murderers or sōshi (thugs). ${ }^{19}$

\section{The Amakasu Incident: Subjectivism in the Military Justice System}

The civilian justice system, as we have seen, was relatively immune to the influence of subjectivism. Military courts, however, shared the culture of the armed services, including adoration of the shishi and their ideals. It also mattered that most judges in court martials were officers without formal training in law, and thus more susceptible to emotional arguments and pressure from their peers. A law from 1921 gave the military justice system exclusive jurisdiction on soldiers, even when they wronged civilians, or committed civil crimes such as murder. Since the early 1920s, an increasing number of right-wing political terrorists were military officers, and therefore that law had crucial repercussions. It ensured that

19 Verdict against Nakaoka Ryōichi and Hashimoto Eigorō, 12.8.1922, reproduced in NSSS 3:334-5. 
many political terrorists received at least some leniency, as long as they skilfully applied the ideals of subjectivism. The courts could show leniency, because the Penal Code of 1907 gave them enormous discretion in sentencing. Sometimes they could choose anything between three years in jail and life imprisonment for the same offence. ${ }^{20}$

The first important example was the Amakasu Trial. On September 16, 1923, during the havoc that followed the Great Kantō Earthquake, a team of military policemen led by Captain Amakasu Masahiko murdered the anarchists Ōsugi Sakae and Itō Noe, along with Munekazu, Ōsugi's six-year old nephew.

The court proceedings were influenced by the general political climate of the time. Large segments of the public detested communists and anarchists and adored the Japanese Army, to which the defendants belonged. The image of the army, which was at a nadir at the beginning of the decade due to the failed Siberian Intervention (1918-1922), greatly improved as a result of the Great Kantō Earthquake. As Leonard A. Humphreys notes, large segments of the public were grateful to the army due to the effective assistance it gave to the population after the disaster (Humphreys 1995, 52-53). Such a climate certainly helped Amakasu and his accomplices. On the other hand, many people, including Prime Minister Yamamoto and Army Minister Tanaka, were aghast by the murder of three Japanese citizens, including a small child (ibid. 57-58; NSSS 3:424-5, 429).

During their trial, Amakasu and his defenders tied the murder to soldierly duties, and ultimately to the shishi ideals of spontaneity, sincerity and pure motives. Amakasu's lawyers argued that national law notwithstanding, the accused spontaneously decided to kill the traitors Ōsugi Sakae and Itō Noe out of an irresistible urge to protect the country. Even the killing of the child could be justified, because it was done for the public good and not for personal interests. The crowd in the courtroom sympathised with such sentiments, and spectators loudly called Amakasu a "hero" (kokushi) during the proceedings, yet another term strongly associated with the shishi in the parlance of the time. The judge did nothing to prevent such interferences from the audience (NSSS 3:428-9).

Amakasu and his lawyers had made a strong emotional appeal here, and while the military procurator rejected their approach he had to compromise with its persuasive power. "It is inadmissible," he said, "to violate the law through direct action." And yet, he said, implicitly recognising the shishi metaphor, Amakasu's crime was a result of excessive enthusiasm in carrying out his duty to protect the country. His motives were pure. He did not act for selfish reasons or for personal interests.

20 “Rikugun Gunpō Kaigihō", 26.4.1921, Kanpō 63, 26.4.1921; Sneider 1990, 14-17. 
The procurator even stated that Amakasu's patriotism "brought tears into one's eyes". For the murder of three defenceless Japanese citizens, one of them a small child, he demanded only 15 years of imprisonment with hard labour for Amakasu, and lesser punishments for the other defendants. The judge gave an even more lenient sentence: only 10 years with hard labour for Amakasu, and three years for the sergeant who murdered Munekazu, the child. The soldiers were acquitted for obeying orders or for lack of evidence ${ }^{21}$ (NSSS 3:427).

This was an extremely light punishment considering the circumstances, but the convicted murderers did not serve even half of it. Almost immediately after the trial, a boisterous public campaign for Amakasu's release began to gather steam. His supporters called him a "patriotic shishi" (yükoku no shishi) and petitioned for his release with no less than 650,000 signatures. Eventually, Amakasu's sentence was commuted for the occasion of the Crown Prince's marriage, and he did not serve even three years (NSSS 3:422, 433).

In other cases, the army and its supporters in the political system strictly refused to punish soldiers who committed political crimes, and subjectivism played an important role in these decisions as well. In October 1931, as described in the introduction to this paper, the military terrorist organisation Sakura-kai plotted to wipe out the Japanese cabinet with naval bombers, poisonous gas and machine gun fire. After their arrest, the chief of the military police gave them extremely lenient treatment-a short detention in a luxurious inn. As noted above, he explained that such generous treatment was in accordance with the "spirit of bushidö" (Orbach 2017, 218).

That statement makes sense only in the context of subjectivism. The imagined way of the samurai was one and the same with the shishi ideals of sincerity and purity of motives (spontaneity was not a feature in the highly-detailed plan of the Sakurai-kai). As one general told a high court official, "though they had to be punished according to the Military Penal Code, the fact that most of them repented and reflected on the error of their ways, and in consideration of their motives, their patriotic spirit and the prestige of the army, they were dealt with in an administrative manner" (Ogata 1984, 100; Oka 1966, 2: 148).

\section{Dark Valley: Assassination Trials and Pure Motives in the 1930s}

In the years 1930-1933 there were three high-profile assassination incidents in Japan: Prime Minister Hamaguchi's assassination, the Ketsumeidan Incident and

21 Verdict against Captain Amakasu Masahiko and four others, 8.12.1923, in NSSS 3: 434-7. 
the May 15, 1932 Incident. The three trials were partly concurrent and had a strong influence on one another. Together, they mark the peak of subjectivist influence on the Japanese legal system.

On 14 November 1930, a civilian named Sagoya Tomeo shot and badly injured Prime Minister Hamaguchi Osachi. Nine months later, in August 1931, Hamaguchi died as a result of medical complications. Sagoya targeted Hamaguchi because he had signed the London Naval Treaty in face of the Imperial Navy's objections, thus violating the prerogative of the armed services to advise the Emperor in matters of national security. ${ }^{22}$

In February and March 1932, three other spectacular assassinations followed. Members of the Ketsumeidan (Blood Pledge Society), a radical right-wing organisation, murdered former Finance Minister Inoue Junnosuke and the business magnate Dan Takuma. That was part of a larger plan to kill 20 leading figures in the realms of business and politics. ${ }^{23}$ Finally, on May 15 of the same year, naval officers (with civilian and army accomplices) shot Prime Minister Inukai Tsuyoshi to death (Sneider 1990, 3-9; Large 2001, 552).

The three ensuing trials were similar in a sense. All three of them (but especially the Ketsumeidan and May Incident Trials) drew intense media attention, and all dealt with questions of patriotism, imperial loyalty and right-wing terrorism. The Hamaguchi and Ketsumeidan tribunals were civilian, while the defendants in the May Incident trial were judged by three different courts according to their affiliation: naval, military and civilian.

At that time subjectivism also gained some traction in Japanese jurisprudence due to growing popularity of new Western legal theories. Since the enactment of the revised penal code in 1907, but especially in the 1920s, a new school of criminal jurisprudence gradually took hold in Japan (Takayanagi 1963, 18; Sneider 1990, 16). It emphasised rehabilitation rather than retribution, and therefore put a greater emphasis on the motives of defendants, as those with pure motives could be reintegrated more easily into the national community. The ideas of this new Western school, which were still in dispute among Japanese jurists in the early 1930s, corresponded well with the indigenous narrative of subjectivism. Therefore, subjectivism was brought up by the defence in all trials, but each court dealt with it in a different manner.

22 Verdict of the lower court against Sagoya Tomeo and Matsumoto Yoshikatsu, 22.4.1932, reproduced in NSSS 4:379-81.

23 For a study of this incident see Large 2001, 533-64. The name Ketsumeidan was given by the prosecutor and has been used in historiography ever since, but was not the formal name of the group. It had none. 


\section{The Hamaguchi'Trial}

Sagoya Tomeo, Prime Minister Hamaguchi's assassin, was first charged with attempted murder in a lower court. After the prime minister died in August 1931, he was convicted of murder and sentenced to death. Subjectivism was neither mentioned nor considered in the verdict. ${ }^{24}$ Sagoya's lawyers, who appealed to the Tokyo District Court, argued that there was no direct causality between the assassination and Hamaguchi's death. The District Court accepted this argument, but still refused to commute the death sentence (NSSS 4:373-6).

The lawyers then appealed again, this time to the Supreme Court. Here, they made extensive use of shishi archetypes, using all possible clichés of subjectivism related to spontaneity, sincerity and pure motives. Most probably influenced by the concurrent Ketsumeidan and May Incident trials, they argued that Sagoya was "a patriotic shishi" motivated by "disinterested anger over public affairs." As the military and its bushido ideology were the mainstays of subjectivism at the time, the lawyers connected Sagoya's motives with the ideals of bushido as well. They insisted accordingly that Sagoya had "our country's ancient, pristine and laudable self-sacrificing spirit of bushidō."Thus, from the point of view of Japanese morality, he should not receive a punishment but rather a reward (NSSS 4:376).

That line of defence was based on the most extreme version of subjectivism, and unlike previous tribunals, the Supreme Court could not ignore it. In partial recognition of the new school of criminal jurisprudence, the court conceded that a defendant's sentence had to consider his motives, character and subjective state of mind, but also other factors which were just as important, such as the position of his victim, the repercussions on the legal order, deterrence of future criminals and other objective and subjective circumstances particular to the case. Sagoya's motives were pure, the court conceded, as the assassination was motivated by patriotism and concern for the public good. Theoretically, such pure motives should serve as mitigating circumstances.

However, the court refused to commute the death sentence. The prime minister was a vital organ of the state, one of the Emperor's chief advisors. To try and replace such a person with violence is not the way of a loyal Japanese subject. The problems of the realm are extremely complicated, and there are different viewpoints. All of them may be patriotic and sincere, but if differences of opinion are settled with violence, the consequences for society might be intolerable.

The court also assailed the shishi ideal of "folly", closely related to sincerity. It is astounding, the judges ruled, that such a politically-ignorant person as Sagoya

24 Verdict against Sagoya Tomeo and Matsumoto Yoshikatsu, 22.4.1932, reproduced in NSSS 4:379-82. 
took on the responsibility to solve the complicated problems of the realm through an illegal act of violence. This was not only criminal, but also incompatible with the ideals of bushido. Instead of fully rejecting the ideals of subjectivism, the court wisely tried to partly criticise and partly accommodate them. But the bottom line was clear: pure motives should not excuse right-wing terrorists (NSSS 4:377-8). Sagoya was finally condemned to death. Despite this, he received an imperial amnesty almost immediately, and had his sentence commuted to life imprisonment. Prime Minister Hamaguchi's murderer then received an amnesty and was finally released in 1940.

\section{The Ketsumeidan Trial}

The trial of Inoue Nisshō, leader of the Ketsumeidan, and his disciples was opened on June 28, 1933, in the Tokyo District court under Justice Sakamaki Teiichirō. In that trial, subjectivism and the ideals of the shishi were explicitly contested in heated debates between the tribunal and the defence team, headed by Amano Tatsuo.

The trial began with a strong denial of subjectivism. Inoue and his disciples, who admired the shishi and saw themselves as their heirs, wanted to elaborate on their motives. However, Judge Sakamaki and his associates refused to listen. In accordance with the old school of criminal jurisprudence, they ordered the defendants to concentrate on the facts of the case. The court's concern was only whether they were guilty as charged, nothing else (NSSS 4:415; Large 2001, 541, 557-8).

In response, Amano and his colleagues launched a concentrated attack on the bench. They lodged several complaints against the judges in the Tokyo Court of Appeals and formally asked for their removal from the case. One of the judges, they argued, was sympathetic to communism and held "anti-Japanese views", because in another case he had refused to sentence communists to death. He judged only in accordance with the evidence, and failed to evaluate defendants according to their spirit and subjective state of mind. Such "anti-Japanese views" were also manifested in the bench's refusal to let Inoue and his friends expound on their motives, loyalty to the Emperor and the Japanese spirit (NSSS 4:418-9).

In fact, the defence accused the tribunal of violating the tenets of subjectivism. If one applied the objective test of evidence, then it is does not really matter whether a defendant was a communist or a pure-hearted adherent of the Emperor. But if the test was subjective, based on state of mind, sincerity and purity of motives, then communists should be executed regardless of what they have done, while patriotic criminals should be exonerated (NSSS 4:409-11). 
The appeals to remove the judges were ultimately rejected by the higher courts, but they shocked Judge Sakamaki to the core, and he delayed the trial indefinitely. This cannot be understood in isolation from the general political climate, the relentless public relations campaign staged by the defence, and the media attention given to this sensational trial. On August 16, Sakamaki took the very unusual step of visiting Inoue in jail to ask for his advice. Inoue treated his judge with contempt, telling him that he [Sakamaki] had indeed learned something, but his "spirit has not yet developed". Sakamaki, clearly shocked and mentally exhausted, declared himself unfit to preside on the tribunal. He delayed the trial again and again, and finally submitted his resignation in November. In an interview, he wearily confessed that legal principles such as proper procedure were not understood "by people not proficient in jurisprudence", and he could not withstand the tide. In a direct clash, subjectivism prevailed over conventional criminal procedure, the new school of criminal jurisprudence over the old ${ }^{25}$ (NSSS 4:415, 419-21, 423-4).

The new judge, Fujii Goichirō, an admirer of the shishi, permitted the defendants to speak about their motives to their heart's content. Even the procurator, who still demanded the death penalty for two of the defendants, could not hide his sympathy for their pure motives. He said that he was compelled to ask for the death penalty, hinting that the prosecution would not object to a more lenient verdict. Indeed, Judge Fujii offered a long and sympathetic description of the defendants' pure motives and their love for the Emperor. He showed some leniency, but to a limited extent. He did not apply the death penalty, and sentenced Inoue and the two murderers to life imprisonment, and the others to varying prison terms. Finally, he expressed hope they would soon be released with an imperial amnesty ${ }^{26}$ (Large 2001, 561; Ōkura 1971,71; Fujii 2010,106). The prosecution decided not to appeal, partly out of sympathy with the defendants' motives, patriotic spirit and the fact that they were not "ordinary murderers". The strong public sentiments in favour of the defendants were another important argument against such an appeal (NSSS 4:427-31).

\section{The May 15 Incident Trial}

The trial of the naval officers who murdered Prime Minister Inukai Tsuyoshi, as well as their army and civilian accomplices, was strongly influenced by the sensational events of the concurrent Ketsumeidan trial. Many media outlets were sympathetic to the motives of the perpetrators, who openly presented themselves as shishi, and published their statements almost without alteration. The presiding

25 The quote from the interview is on p. 424.

26 Verdict against Inoue Nisshō and 13 others, 22.11.1934, reproduced in NSSS 4:440-3. 
judge in the navy tribunal wanted to avoid the fate of Sakamaki, and therefore decided to permit the defendants to speak at length about their motives (NSSS 4:425; Sneider 1990, 9-11).

The army leaders were quick to ride this wave. When the perpetrators were arrested, the chief of the military police ordered that they be treated "as patriots". Army Minister Araki publicly mourned the fate of the pure, naive and sincere officers who acted selflessly for the country. His naval counterpart, Admiral Ōsumi Mineo, lamented the fate of his officers in similar terms. That sentiment was reflected in the policy of both armed services. Unlike the civilian defendants, who were charged with murder and attempted murder, the soldiers were charged with rebellion. The army and the navy saw them as misguided patriots, not as ordinary criminals (Sneider 1990, 9, 12, 19-20; Fujii 2010, 112).

The defence lawyers (one of whom represented Amakasu in 1923) made full use of such sentiments. When faced with such noble motives, they said, the court had to refrain from applying the law, acknowledging instead the purity of the defendants, their character, and the revolutionary momentum engulfing Japanese society. They went on to elaborate on the precedent of the shishi, concluding that pure-hearted loyalty to the Emperor was the spirit of the law, a mysterious sentiment that only Japanese subjects could understand. Judging the defendants severely would undermine that lofty spirit, destroying the very basis of the Japanese national polity. This extreme version of subjectivism went much further than even the new school of criminal jurisprudence. In fact, it went beyond the confines of jurisprudence altogether, venturing to the realm of romantic mysticism (Sneider 1990, 32-7).

In response, Navy Procurator Yamamoto Kōji attacked not only the defendants, but also the ideology of subjectivism they were utilising to get themselves off the hook. Sticking to the old school of criminal jurisprudence, the procurator emphasised that political violence should be punished mercilessly regardless of the perpetrators' motives, patriotism or alleged loyalty to the emperor. A pure motive cannot whitewash an illegal action, especially not by soldiers. Army and navy personnel should avoid politics and stick to the law as prescribed in the Imperial Rescript for Soldiers and Sailors and the military penal codes. Otherwise, he warned, political violence would plague and ultimately imperil the nation. Yamamoto, who rejected subjectivism in toto, paid dearly for his bravery. A tsunami of public censure forced him to resign from the navy, practically destroying his legal career. ${ }^{27}$

The naval judges rejected Yamamoto's view, elaborating instead on the pure-hearted patriotism of the defendants. Accordingly, the punishments for the main

27 See Yamamoto's plea, fully reproduced in Tomioka 1933, and especially pp. 289-94. For analysis see: Sneider 1990, 28-32, 40-1. 
offenders were relatively lenient: fifteen years in jail, instead of the execution and life imprisonment demanded by the prosecution. "Although their [the defendants'] criminal culpability is truly significant," ruled the president of the court, "the depth of their patriotism must be acknowledged" (Sneider 1990, 38).

The army court was even more lenient, and its emphasis on the defendants' purity of motives was significantly more pronounced. The civilian court agreed to listen at length to the motives of the defendants, but it was the strictest of the three. The presiding judge sentenced the two main defendants to life imprisonment, and did not emphasise their motives in the verdict. That strictness was, however, superficial. In private, the judge expressed sympathy with the ideals of the defendants, though not with their violent methods, and made sure the sentence would be proclaimed on time for the upcoming imperial amnesty. Three of the defendants appealed to higher courts, where their motives were more explicitly acknowledged and their sentences significantly reduced (ibid. 24-5, 37-47).

\section{The Crescendo and Decline of Subjectivism: The Nagata and February 1936 Incident Trials}

On August 22, 1935, Lieutenant-Colonel Aizawa Saburō, a military fencing instructor, responded to what he later called a spontaneous "impulse from on high". He assassinated Major General Nagata Tetsuzan, a leader of a rival military faction whom he denounced as "the headquarters of all evil". According to Aizawa, his victim was a member of the privileged class and a traitor who showed disrespect for the Emperor by purging ultra-nationalistic officers (NSSS 5:153-4; Byas 1942, 95, 111).

Aizawa's court martial followed the same pattern as the May 1932 Incident trial. Knowing full well that there was no possible legal way to dismiss the murder charges against his client, defence counsel Lt. Col. Mitsui Sakichi used the same strategy which had worked so well in previous proceedings-making an emotional appeal to subjectivism. Aizawa was thus presented as sincere and pure, and his burning love of Emperor and country had forced him to act spontaneously against a person he saw as an enemy from within. "The young officers are pure as water, innocently flowing forward," Mitsui said, "if there is a wave, it is caused by the wind." 28

Following the example set by Inoue Nisshō in the Ketsumeidan trial, Aizawa yelled at the judge from the witness stand. His defence team also presented bountiful

28 See Mitsui's written plea in Niniroku Jiken Hiroku, edited by Hayashi Shigeru (1971-2, 1: 26-29). The quote is from p. 26. 
letters of support from the public, including one written by high school girls in their own blood, as well as a jar containing a chopped finger, signifying the senders' sincere readiness to die in place of the defendant. A Soviet diplomat who attended the trial was astounded that junior officers dared to publicly insult the Emperor's closest advisors. The trial, he reported, was crazy enough to offer rich research material for psychologists and even psycho-pathologists. ${ }^{29}$

However, while Aizawa's trial was unfolding rebellious officers unleashed the largest military uprising that Japan saw in the twentieth century. On February 26,1936 , they mobilised more than 1,400 troops in Tokyo, and assassinated two civilian leaders and two senior officers. Others, such as Prime Minister Okada Keisuke, had a narrow escape or suffered serious injuries. In the beginning, the army leaders dragged their feet, but Emperor Hirohito's direct intervention forced them to move against the rebels. The mutiny was finally crushed on February 29, but its echoes reverberated far and wide. The entire top-tier of the army abdicated, and the succeeding military leadership took some stringent measures to restore discipline. ${ }^{30}$

The ringleaders of the incident, all of them young lieutenants, captains and majors, believed that they would enjoy the benefits of subjectivism, like their naval peers in 1932. In their own self-perception they were modern shishi, committed to the ideals of spontaneity, sincerity and purity. Many of them were educated in specialised military institutions, and grew up on shishi stories. They acted spontaneously, without thorough planning, out of righteous indignation towards the privileged classes, and did so for the nation, the emperor and the entire world. Needless to say, they were more than ready to die for their cause. ${ }^{31}$

But the February 1936 rebels had a very unpleasant surprise. The magic of subjectivism had stopped working. Their court martial was held behind closed doors, blocking the flow of media attention that helped their predecessors during the May 1932 and Ketsumeidan trials. They were allowed to speak about their motives, but the judges were unsympathetic. In fact, the defendants' purity counted for nothing. All the ringleaders and many other participants were sentenced to death,

29 Yurenev to the Deputy People's Commissar for Foreign Affairs, 25.4.1936, Arhiv Vneshnei Politiki Rossiskei Federatsii (1936, 154(4)-5(3)). The British journalist Hugh Byas had a similar impression. Though, as an old Japan hand, he was much less surprised than Yurenev. See: Byas 1942, 99-100.

30 For a detailed account of the February Incident, see Orbach 2017, 225-57.

31 Kurihara's Interrogation, Nakahashi's Interrogation, Hayashi's interrogation, Suzuki's Interrogation, Ikeda's interrogation, Muranaka's interrogation, Isobe, "refutation", $N R J H, 135,157-8,177$, 189, 208, 255, 4:19; Isobe 1971, 314; 1961, 111, 258, 126-7; Isobe 1972, 54; Suzuki 1971-1794, 136; Shillony 1973, 214. 
and no imperial pardons were given. Aizawa Saburō, General Nagata's assassin, was executed as well (Orbach 2017, 251-2).

Emperor Hirohito's direct intervention against the rebels had drawn all oxygen from their subjectivist balloon. According to subjectivist ideology, spontaneity, sincerity and pure motives were a necessary but not a sufficient condition. One had to be first and foremost an imperial loyalist. As long as the Emperor was silent, as was usually the case, even rebels could present themselves as imperial loyalists. But when the Emperor directly intervened against them, such arguments became null and void. Subjectivism, it seemed, stood on one objective pillar: imperial silence. When that was broken, right-wing terrorists could not use subjectivist defences. The events of February 1936 proved that the weak position and non-intervention policy of the Emperor were essential for the leniency that right-wing terrorists, especially from the armed services, enjoyed up to that crucial year.

\section{Conclusion}

In this paper, I have argued that the relative judicial leniency to right-wing terrorists in the early 1930s was interlinked with the deep-rooted ideology of subjectivism. This ideology, based on the mythologization of the shishi, had three main tenets: spontaneity, sincerity and pure motives, defined as an intention to serve the Emperor, the country and the public good. Up to the 1920s, this ideology had strong currency as a cultural narrative, but its influence on the justice system was relatively modest.

Since the assassination of Yasuda Zenjirō in 1920 and the subsequent murder of Prime Minister Hara Kei in 1921, subjectivism played an important part in the arguments of the assassins, their defence lawyers and supporters in the public and press. However, up to the early 1930s, civilian courts were by and large unimpressed. The situation was very different, however, in military courts. Since 1921, these had exclusive jurisdiction with regard to military criminals, even murderers who killed civilians. Echoing the relative strength of shishi myths in military culture, court martials were much more attentive to subjectivist arguments, such as during the Amakasu trial in 1923. The proceedings against the Ketsumeidan defendants between 1932 to 1934 had shown that subjectivism overflowed to the civilian justice system as well, perhaps abetted by the growing popularity of a new school of criminal jurisprudence. The sensational events of the Ketsumeidan trial, in turn, reinforced these notions in the military justice system in a process of positive feedback. Following the Incident of May 1932, the navy and the army court martials showed relative 
leniency to officers who committed the grave political crime of assassinating the prime minister. The same tendency continued in the trial of Aizawa Saburō, who murdered Major General Nagata Tetsuzan in 1935, but was reversed after the Incident of February 26, 1936. The direct intervention of the emperor nullified a crucial tenet of subjectivism: pure motives, which were identical with imperial loyalty.

Although subjectivism was important as a cultural narrative throughout the history of modern Japan, its influence on political justice was limited to a relatively short period, and even then, mostly to military and naval court martials, although its historical repercussions were significant. The leniency shown to military rebels such as the ringleaders of the Sakurai-kai and the assassins of the May 1932 Incident encouraged copycats, finally making the seminal events of February 1936 possible. The February coup, though abortive, convinced the civilian leadership of Japan that the army had to be accommodated in order to prevent such occurrences in the future. As a result, it led to growing dominance of the army in national politics (Orbach 2017, 255-6). As the journalist Hugh Byas maintained, "The army installed itself in power with the concurrence of a docile nation intoxicated by foreign war, its civilian leaders terrorised by assassination" (Byas 1942, 39). The ideology of subjectivism, which helped to encourage such assassinations, thus has to be considered as one of the factors that pushed Japan towards militarism, unmitigated aggression, the war against China and finally the Pacific War.

\section{References}

Arhiv Vneshnei Politiki Rossiskei Federatsii (Archive of Foreign Policy of the Russian Federation, Moscow), Opis 19, Delo 76, Papka 175: 154(4)-155(3). Beasley, William. 1972. The Meiji Restoration. Stanford: University of California Press.

Benesch, Oleg. 2014. Inventing the Way of the Samurai: Nationalism, Internationalism and Bushido in Modern Japan. Oxford: Oxford University Press.

Byas, Hugh. 1942. Government by Assassination. New York: A.A.Knopf.

Chae, Soo Do 蔡 数道. 2001. “Tenyūkyō’ ni kansuru ikkōsatsu 典裕狭に関す る一考察 (An Inquiry on the Tenyūkyō)." Chūō Daigakuin Kenkyū Nenpō: Hōgaku Kenkyūka 30, February: 439-50.

Cooper, Leo. 2000. In the Shadow of the Polish Eagle: The Poles, The Holocaust and Beyond. New York: Palgrave.

Craig, Albert M. 1961. Chōshū in the Meiji Restoration. Cambridge: Cambridge University Press.

Etō, Shimpei 江藤新平. 1914. Etō Nanpaku 江藤南白, vol. 2. Tokyo: Nanpaku Kenshōkai. 
Fujii, Hisashi 藤井非三四. 2010. Niniroku Teito Heiran: Gunjiteki Shiten kara zenmenteki ni minaosu二・二六帝都兵乱：軍事的視点から全面的に見 直寸 (The February 26, 1936 Military Uprising in the Imperial Capital: A Complete Reassessment from a Military Perspective). Tokyo: Sōshisha. Fukushima, Nariyuki 福島成行. 1927. Akasaka Kuichigai no Jihen: Seikanron no Yobun 赤坂喰違の事変 : 征韓論の余聞 (The Incident of Kuichigai in Akasaka: Rumors of the 'Occupying Korea' Debate). Tokyo: Maeda Bajōta. Gumpel, Emil J. 1922. Vier Jahre politischer Mord. Berlin-Fichtenau: Verlag der Neuen Gesellschaft.

Haley, John. 1991. Authority without Power: Law and the Japanese Paradox. New York: Oxford University Press.

Hall, Ivan P. 1973. Mori Arinori. Cambridge, MA: Harvard University Press. Harutoonian, Harry D. 1970. Toward Restoration: The Growth of Political Consciousness in Tokugawa Japan. Berkeley: University of California Press. Hayashi, Shigeru 林茂, ed. 1972-1972. Niniroku Jiken Hiroku二二六事件秘録 (Secret Records of the February 26 Incident), vol. 1. Tokyo: Shōgakkan.

Hirano, Ryuichi. 1963. "The Accused and Society: Some Aspects of Japanese Criminal Law." In Law in Japan: The Legal Order in a Changing Society, edited by Arthur Taylor von Mehren, 274-97. Cambridge MA: Harvard University Press.

Huber, Thomas. 1982. "Men of High Purpose and the Politics of Direct Action, 1862-4." In Conflict in Modern Japanese History: The Neglected Tradition, edited by Tetsuo Najita and J. Victor Koschmann, 107-27. Princeton: Princeton University Press.

Humphreys, Leonard A. 1995. The Way of the Heavenly Sword: The Japanese Army in the 1920s. Stanford, Calif.: Stanford University Press.

Ichikawa, Masaaki 市川正明, ed. 1953. “Kankoku Ōhi Satsugai Jiken 韓国王 妃殺害事件 (The Assassination Incident of the Korean Queen).” In Nikkan Gaikō Shiryō 日韓外交史料 (Historical Documents on Korean-Japanese Diplomacy), vol. 5. Tokyo: Hara Shobō.

Isobe, Asaichi 磯部浅一.1971. “Gokuchū Shuki 獄中手記 (Notes from Prison).” In Jungyaku no Shōwa shi: 2-26 Jiken made no Rikugun 順逆の昭和史 : 二・二六事件までの陸軍 (Showa History of Obedience and Disobedience: The Army until the February 26 Incident), edited by Tahei Takamiya, 293319. Tokyo: Hara Shobō.

—, 1972. “Kōdōki 行動記 (Action Account)." In Niniroku Jiken: Gokuchū Shuki, Isho 二 ・ 二六事件-獄中手記 - 遺書, edited by Kōno Tsukasa 河野 司 , 225-385. Tokyo: Kawade Shobō Shinsha.

Jansen, Marius B. 1994. Sakamoto Ryōma and the Meiji Restoration. New York: Columbia University Press. 
Jōhō, Yoshio 上法快男, 1973. Rikugun Daigakkō. 陸軍大学校 (The Army Staff College). Tokyo: Fuyō Shobō.

Kikuchi, Kenjō 菊池謙諈. 1896. Chōsen Ōkoku. 朝鮮王国 (The Korean Kingdom). Tokyo: Minyūsha.

Kingsberg, Miriam. 2014. Moral Nation: Modern Japan and Narcotics in Global History. Berkeley: University of California Press.

Keiji Soshohō,1890-1891. Article 165, pp. 50-1. Osaka: Osaka Asahi Shinbun sha.

Online version see: http://kindai.ndl.go.jp/info:ndljp/pid/795135/31.

Kobayakawa, Hideo 小早川秀雄, 1900. Bingō Soraku Jiken. 閔后殖落事件 (Incident of the Vampire Queen Min). Tokyo: Modern Japanese Political History Materials Reading Room, National Diet Library.

Kuzu, Yoshihisa葛生能久 (Kokuryūkai 黒龍会), ed. 1933-1936. Tōa Senkaku Shishi Kiden 東亜先覚志士紀伝 (Biographical Accounts of the Shishi Pioneers of East Asia). Tokyo: Hara Shobō. 3 vols.

Large, Stephen S. 2001. "Nationalist Extremism in Early Shōwa Japan: Inoue Nisshō and the 'Blood-Pledge Corps Incident', 1932." Modern Asian Studies 35 (3): 533-64.

Lebra, Joyce C. 1973. Ökuma Shigenobu: Statesman of Meiji Japan. Canberra: Australian National University Press.

Lyotard, Jean-Francois. 1988. The Differend: Phrases in Dispute, translated by Georges van den Abbeele. Minneapolis: University of Minnesota Press.

Mackie, Vera, and Susumu Yamaizumi. 2013. "Introduction." In Japan and the High Treason Incident, edited by Masako Gavin and Ben Middleton, 1-15. Milton Park, Abingdon, Oxon: Routledge.

McElligott Anthony. 2014. Rethinking the Weimar Republic: Authority and Authoritarianism, 1916-1936. London: Bloomsbury Academic.

Mitchell, Richard H. 1992. Janus-Faced Justice: Political Criminals in Imperial Japan. Honolulu: University of Hawaii Press.

Morris, Ivan. 1998. The Nobility of Failure: Tragic Heroes in the History of Japan. New York: Noonday Press.

National Archives of Japan, Digital Archive, 12.8.1913. Junkoku Shishi Hyōshō Tsuiroku Seigan no Ken 殉国志士表彰追録請願の件 (Applications for Commendation of Shishi Martyred for the Country: An Addendum), Gyōsei Bunsho, Naikaku Sōrifu, Dajōkan-Naikaku Kankei:1, Kumon Zassan Taishō 2-nen, vol. 35, Teikoku Gikai 2, call number 2A-013-00.

Matsumoto, Sōji 1937. “Ishin no Shishi o ronzu. 維新の志士を論ず (Discussing the Shishi of the Meiji Restoration).” In Kagayaku Rikugun Shōkō Seito 輝 <陸軍将校生徒 (Brilliant Army Cadets), vol. 2, edited by Amakasu Shigetarō, 7-13. Tokyo: Rikugun Yoka Shikan Gakkō. 
Norman, E.H. 1944. "Genyōsha: A Study in the Origins of Japanese Imperialism." Pacific Affairs 17 (3), September: 261-84.

Ogata, Sadako, 1984. Defiance in Manchuria: The Making of Japanese Foreign Policy, 1931-2. Westport, CT: Greenwood Press.

Oka, Yoshitake 岡義武, ed. 1966. Kido Köichi Nikki 木戸孝允日記 (The Diary of Kido Köichi), vol. 2. Tokyo: Tokyo Daigaku Shuppankai.

Ōkuma, Shigenobu 大隈重信. 1969. “Ōkuma Shigenobu wa kataru: kokon tōzai jinbutsu hyōron 大隈重信は語る：古今人物評論 (Ōkuma Shigenobu speaks: A Review of People Past and Present, East and West)." In Ökuma Shigenobu sōsho 大隈重信叢書 (Ōkuma Shigenobu Library), vol. 1. Tokyo: Waseda Daigaku Shuppanbu.

Ōkura, Eiichi 大蔵 栄一. 1971. Niniroku Jiken e no Banka: Saigō no Seinen Shōkō二・二六事件への挽歌 : 最後の青年将校 (An Elegy to the February Incident: The Last Young Officer). Tokyo: Yomiuri Shinbunsha.

Orbach, Danny. 2017. Curse on This Country: The Rebellious Army of Imperial Japan. Ithaca: Cornell University Press.

Person, John D. 2017. "Between Patriotism and Terrorism: The Policing of Nationalist Movements in 1930s Japan.” The Journal of Japanese Studies 43 (2), Summer: 289-319.

Plutschow, Herbert. 2002. "Ideology and Historiography: The Case of Sugawara no Michizane in the Nihongiryaku, Fusō Ryakkai and the Gukanshō.” In Historiography and Japanese Consciousness of Values and Norms, edited by Joshua C. Fogel and James C. Baxter, 133-45. Kyoto: International Research Center for Japanese Studies.

Sagara, Shunsuke 相良俊輔. 1978. Akai Yūhi no Manshū Nogahara ni: Kisai Kōmoto Daisaku no Shōgai 赤い夕陽の満州野が原に：鬼才河本大作の 生涯 (Red Sunset on the Plains of Manchuria: The Career of the Genial Kōmoto Daisaku). Tokyo: Kōjinsha.

Sasaki, Suguru 佐々木克. 1984. Shishi to Kanryō: Meiji Shonen no Jōkei 志士と 官僚：明治初年の場景 (Shishi and Administrators: The Scene of the Early Meiji Era) Kyoto: Mineruva Shobō.

Satow, Ernest M. 1998. A Diplomat in Japan. Bristol: Ganesha pub.; Tokyo: Edition Synapse.

Sekigawa Natsuo 関川夏央. 1994. “Tairiku rōnin to gunji tantei 大陸浪人と 軍事探偵 (The Continental Adventurers and Military Espionage).” Bungaku-kai 48 (6): 246-9.

Shillony, Ben Ami. 1973. Revolt in Japan: The young Officers and the February 26, 1936 Incident. Princeton, N.J.: Princeton University Press.

Shinkoku.exblog 2008. “Asahi Heigo-shi no Seimei” 朝日平吾氏の声明, accessed: 3.6.2018. http://shinkoku.exblog.jp/10012543/. 
Siniawer, Eiko Maruko. 2008. Ruffians, Yakuza, Nationalists: The Violent Politics of Modern Japan. Ithaca: Cornell University Press.

Sneider, David A. 1990. "Action and Oratory: The Trials of the of the May 15th Incident of 1932." Law in Japan 23 (67): 1-66.

Suematsu, Tahei 末松太平 1963. Watakushi no Shōwashi 私の昭和史 (My Shōwa History). Tokyo: Misuzu Shobō.

Suzuki, Teiichi 鈴木貞一.1971-1974. Suzuki Teiichi-shi Danwa Sokkiroku 鈴木 貞一氏談話速記 (Records of the Conversations of Mr. Suzuki Teiichi), vol.1. Tokyo: Nihon Shiriyō Kenkyūkai.

Takata, Yūsuke 高田 祐介. 2012. “Meiji Ishin 'shishi'-zō no Keisei to Rekishi Ishiki 明治維新志士像の形成と歴史意識 (Formation and Historical Consciousness of the Image of Shishi in the Meiji Restoration)." Rekishi Gakubu Ronshū: Bukkyō Daigaku Rekishi Gakubu 2, March: 43-70.

Takayanagi, Kenzō. 1963. "A Century of Innovation: The Development of Japanese Law, 1868-1961.” In Law in Japan: The Legal Order in a Changing Society, edited by Arthur Taylor von Mehren, 5-40. Cambridge MA: Harvard University Press.

Tomioka, Fukujirō 富岡福寿郎. 1933. Go-ichigo to Ketsumeidan 五・一五と 血盟団 (The May 15th Incident the Blood Pledge League). Mito: Kōbunsha. Tsunoda, Jun 角田順, ed. 1968-1971. Ugaki Kazushige Nikki. 宇垣一成日記 (The Diary of Ukagi Kazushige), vol. 1. Tokyo: Misuzu Shobō.

Tsunoda, Ryusaku et. al, eds. 1958. Sources of Japanese Tradition. New York: Columbia University Press.

Suzaki, Shin’ichi 須崎慎一. 2003. Niniroku Jiken: Seinen Shōkō no Ishiki to Shin$r i$ 二・二六事件：青年将校の意識と心理 (The February 26 Incident: The Consciousness and Mentality of the Young Officers). Tokyo: Yoshikawa Kōbunkan.

Wagatsuma, Sakae 我妻栄 et al., eds. 1968-1970. Nihon Seiji Saiban Shiroku 日 本政治裁判史録 (Historical Record of Japan's Political Trials: Meiji), vols 1,2 and 4. Tokyo: Daiichi Hōki Shuppan. In the text also NSSS.

Walthall, Ann. 1998. The Weak Body of a Useless Woman: Matsuo Taseko and the Meiji Restoration. Chicago: University of Chicago Press. 